\title{
New PCR Test for Detection of Candida glabrata Based on the Molecular Target Chosen by the RAPD Technique
}

\author{
ANNA OLCHAWA ${ }^{1}$, BEATA KRAWCZYK ${ }^{1}$ and ANNA BRILLOWSKA-DĄBROWSKA ${ }^{1 *}$ \\ ${ }^{1}$ Department of Microbiology, Gdańsk University of Technology, Poland
}

Received 6 September 2012, revised 24 September 2012, accepted 24 September 2012

\author{
Abstract
}

Rapid, reliable diagnosis is a necessary condition for the successful treatment of infections. Such diagnostic assays are continually being developed. The paper presents a method for selecting the molecular target for PCR-based diagnostics based on the comparison of RAPD patterns. A sequence encoding Candida glabrata CBS138 hypothetical protein was selected. The limit of detection for PCR and real-time PCR reactions with DNA extracted from blood samples spiked with Candida glabrata was estimated at $1 \mathrm{CFU} / \mathrm{ml}$. The application of the assays developed in this study would thus seem to be promising as a complementary method in the diagnostics of C. glabrata infections.

Ke y words: Candida glabrata, molecular targets, PCR, RAPD, real-time PCR

The number of sequenced genomes and fragments of DNA sequences of pathogenic microorganisms continues to increase. However, some problems still remain as regards the choice of molecular targets for the design of primers for PCR detection and identification.

In this paper, we present a method based on the RAPD technique for the identification of the molecular target for PCR detection applied to Candida glabrata DNA. To date, a number of different PCR tests for PCR identification of this pathogen have been published. Some are based on the sequences of lanosterol-alphademethylase and chitin synthase (Burgener-Kairuz et al., 1994; Jordan et al., 1994). The regions of ribosomal DNA are probably the most often applied as the molecular targets in PCR diagnostics of pathogenic fungi (Mecler and Nawrot, 2008; Fujita et al., 2001; Chen et al., 2001; Luo et al., 2002). The golden standard of Candida species identification in reference mycology laboratories is the sequencing of ITS fragments. However, as the NCBI database relies on the work of the authors of the deposited sequences being correct, there are, in fact, a number of incorrectly identified sequences (Ciardo et al., 2006).

We describe the PCR and real-time PCR assay for the specific detection of the DNA of Candida glabrata. The primers for the assays were designed on the basis of the C.glabrata sequence identified by comparison of the RAPD patterns which were obtained for differ- ent Candida species. We selected the identification of C. glabrata as the aim of the PCR-based assays thus developed because this fungus is one of the pathogens affecting an increasing number of patients (Fidel et al., 1999; Pfaller et al., 2003; Lyon et al., 2010). An additional problem related to C.glabrata infections is its resistance to antimycotics (Lyon et al., 2010). It is estimated that approx. $60 \%$ of the C. glabrata strains isolated from ICU patients are resistant to fluconazole, which is first line antimycotic applied in hospitals.

The clinical and reference strains used in the presented study for the identification of molecular targets and evaluation of the PCR designed for the specific detection of C. glabrata came from the collection of the Department of Microbiology at the Gdansk University of Technology. The breakdown of the strains is as follows: 37 clinical and 10 reference C.albicans, 30 clinical and 1 reference C. glabrata, 12 clinical and 1 reference C. tropicalis, 9 clinical and 1 reference C. parapsilosis, 2 C.famata, 1 C.dublinensis, 1 C.guillerandalis, 2 C. kefyr, 1 Saccharomyces cerevisiae, 1 C. sake, 3 C. guilleromondi, 3 C. krusei, and 1 C. lusitaniae. The Escherichia coli TOP10F' strain was applied for the cloning of the PCR products selected. The DNA of the microorganisms was purified in line with the Genomic Mini AX Yeast (A\&A Biotechnology) protocol. Evaluation of the DNA concentration was performed with the NanoDrop ND-1000 (Thermo Scientific, Germany)

\footnotetext{
* Corresponding author: A. Brillowska-Dąbrowska, Technical University of Gdańsk, Department of Microbiology; Narutowicza 11/12,
} 80-233 Gdańsk, Poland; phone: +48 5834724 06; fax: +48 5834718 22; e-mail: annbrill@pg.gda.pl 
and was placed between 8 and $1161 \mathrm{ng} / \mu \mathrm{l}$ for individual strains. For RAPD purposes, a DNA concentration of up to $30-40 \mathrm{ng} / \mu \mathrm{l}$ was established for all of the samples. The $50 \mu \mathrm{l}$ master mixes were prepared directly prior to amplification and consisted of $1 \mu \mathrm{l}(0,5 \mathrm{U} / \mu \mathrm{l})$ of DNA polymerase Pwo Hypernova (DNA-Gdansk II, Poland), $5 \mu \mathrm{l}$ of PCR reaction buffer (DNA-Gdansk II, Poland), $5 \mu \mathrm{l}$ of $20 \mathrm{mM} \mathrm{MgCl}, 5 \mu \mathrm{l}$ of $25 \mathrm{mM}$ dNTP's, $2 \mu \mathrm{l}$ of $10 \mu \mathrm{M} 1247$ primer (5' AAGGACCCGT $3^{\prime}$ ), and $2 \mu \mathrm{l}$ of $10 \mu \mathrm{M}$ of 1290 primer (5' GTGGATGCGA 3'). The reaction was performed in the Mastercycler (Eppendorf) and comprised the following stages: $6 \mathrm{~min}$ of preliminary denaturation in $94^{\circ} \mathrm{C}$ followed by 40 cycles: $1 \mathrm{~min}-94^{\circ} \mathrm{C}, 1 \mathrm{~min}-38^{\circ} \mathrm{C}$ and $1 \mathrm{~min}-72^{\circ} \mathrm{C}$. The final elongation lasted $6 \mathrm{~min}$ at $72^{\circ} \mathrm{C}$. The RAPD products for particular strains were run by electrophoresis in $6 \%$ polyacrylamide gel stained with ethidium bromide and visualized in UV light. Products specific to C. glabrata strains were selected and excised from the $1 \%$ agarose gel by means of a Gel-out kit (A\&A Biotechnology, Poland). The products were cloned into the pJET1.2 vector in line with the manufacturer's protocol (Fermentas, Lithuania) and used for the transformation of the E. coli TOP10F' strain. Plasmid DNA was extracted (Plasmid Mini, A\&A Biotechnology, Poland) from the E. coli colonies cultured for $16 \mathrm{~h}$ at $37^{\circ} \mathrm{C}$ on the Luria Agar in the presence of ampicillin $(100 \mu \mathrm{g} / \mathrm{ml})$. The inserts from the recombinant plasmids were sequenced by the Genomed (Poland) with the pJET1.2 forward (5' CGACTCACTATAGGGAGAGCGGC 3') and pJET1.2 reverse (5' AAGAACATCGATTTTCCATGGCAG 3') primers. The sequences obtained were blasted against the NCBI database. The C. glabrata specific PCR was performed in conditions dexribed below. A $0.5 \mu \mathrm{l}$ of $10 \mathrm{mM}$ solution of each primer was applied with $2.5 \mu$ of PCR reaction buffer (DNA-Gdansk II, Poland), $2.5 \mu \mathrm{l}$ of $20 \mathrm{mM} \mathrm{MgCl}, 2.5 \mu \mathrm{l}$ of $25 \mathrm{mM}$ dNTP's, $0.5 \mu \mathrm{l}$ of DNA polymerase Pwo Hypernova (DNA-Gdansk II) and $5 \mu$ lof the extracted DNA in the $25 \mu \mathrm{l}$ reaction mixture. The amplification profile consisted of an initial incubation of $3 \mathrm{~min}$ at $94^{\circ} \mathrm{C}$ followed by 40 cycles of $45 \mathrm{~s}$ at $94^{\circ} \mathrm{C}, 30 \mathrm{~s}$ at $63^{\circ} \mathrm{C}$ and $45 \mathrm{~s}$ at $72^{\circ} \mathrm{C}$, with a final $10 \mathrm{~min}$ hold at $72^{\circ} \mathrm{C}$. The PCR products were separated by agarose gel electrophoresis ( $2 \%$ agarose containing $0.5 \mu \mathrm{g} / \mathrm{ml}$ ethidium bromide in $1 \times \mathrm{TBE}$ buffer) and analyses.

The $20 \mu$ l of real-time PCR mixture consisted of $0.5 \mu \mathrm{l}$ of a $10 \mathrm{mM}$ solution of each primer, $10 \mu \mathrm{l}$ Real Time 2x PCR Mix SYBR B, water and $5 \mu$ of the extracted DNA. The reaction was performed in the LightCycler 1.5 (Roche Applied Science) under the following conditions: pre-incubation: $3 \mathrm{~min}$ in $95^{\circ} \mathrm{C}$, amplification: $10 \mathrm{sec}$ in $94^{\circ} \mathrm{C}, 10 \mathrm{sec}$ of primers annealing at $63^{\circ} \mathrm{C}$ and $10 \mathrm{sec}$ of product elongation at $72^{\circ} \mathrm{C}$. The reaction was followed by a melting curve analysis $\left(1 \mathrm{~min}\right.$ at $95^{\circ} \mathrm{C}$, cooling for $1 \mathrm{~min}$ at $65^{\circ} \mathrm{C}$, and ramp to $95^{\circ} \mathrm{C}$ at a ramp rate of $0.1^{\circ} \mathrm{C} / \mathrm{s}$ ).

In order to estimate the primers' limit of detection from a blood specimen dilution of C. glabrata, $1 \mathrm{ml}$ of EDTA-anticoagulated whole blood sample from a healthy donor was spiked with $30 \mu \mathrm{l}$ of 24-hour C. glabrata culture. Serial dilutions of the inoculated blood samples were made and the fungal suspensions were concurrently and successively diluted in phosphate buffered saline. $200 \mu \mathrm{l}$ of each dilution of saline and the corresponding blood specimen were used for total DNA extraction in line with a modified Genomic Mini AX Yeast (A\&A Biotechnology, Poland) protocol: $0.2 \mathrm{ml}$ spheroplast buffer, $50 \mu \mathrm{l}$ of chitinase and $15 \mu \mathrm{l}$ $1 \mathrm{M} \mathrm{DTT}$ were added to the tubes containing the spiked samples, then mixed and incubated for $30 \mathrm{~min}$ at $50^{\circ} \mathrm{C}$. The next stages of purification were performed as per the manufacturer's protocol. The precipitated DNA was re-suspended in various volumes of TB buffer. Fungal counts for each dilution in blood and saline were performed in triplicate and enumerated on Sabouraud agar. The numbers of colony-forming units $\left(10^{10}\right.$ to $10^{\circ} \mathrm{CFU} / \mathrm{ml}$, in serial dilutions) were compared to the presence of $272 \mathrm{bp}$ PCR product, in the case of PCR reaction, and to the presence of the PCR products exhibiting a melting temperature of $86^{\circ} \mathrm{C}$ in the case of real-time PCR.

The aim of this study was the selection of a molecular target on the basis of a comparison of different RAPD patterns appropriate to the designing of primers for PCR identification of Candida glabrata. The selected molecular target should be common for different C. glabrata strains and its specificity should be confirmed within the species which can be found in the specimens under investigation. The RAPD reactions for identification of the C. glabrata specific products representing the specific molecular target were performed with DNA from 3 C. glabrata, 14 C. albicans, 2 C. parapsilosis, 1 C. tropicalis, 1 C. kefyr and 1 C. krusei strains. The specific PCR product presented only within the RAPD patterns obtained for C. glabrata was selected (Fig. 1.). Confirmation of the versatility of approximately $1300 \mathrm{bp}$ product's presence was performed by running an RAPD reaction for 9 different strains of C. glabrata isolated in different geographical areas of Poland, namely, Gdańsk, Szczecin and Warsaw and, additionally, from Sweden. Comparison of the RAPD patterns obtained enabled identification of specific product present only in C. glabrata RAPD profiles to be identified. As the different RAPD products can be synthesized on the basis of the same genes, the cloning of the selected product is important. It allows the reading of the whole sequence of the product selected. Such precautions guaranteed that sequence specific primers for the C. glabrata DNA were obtained. 


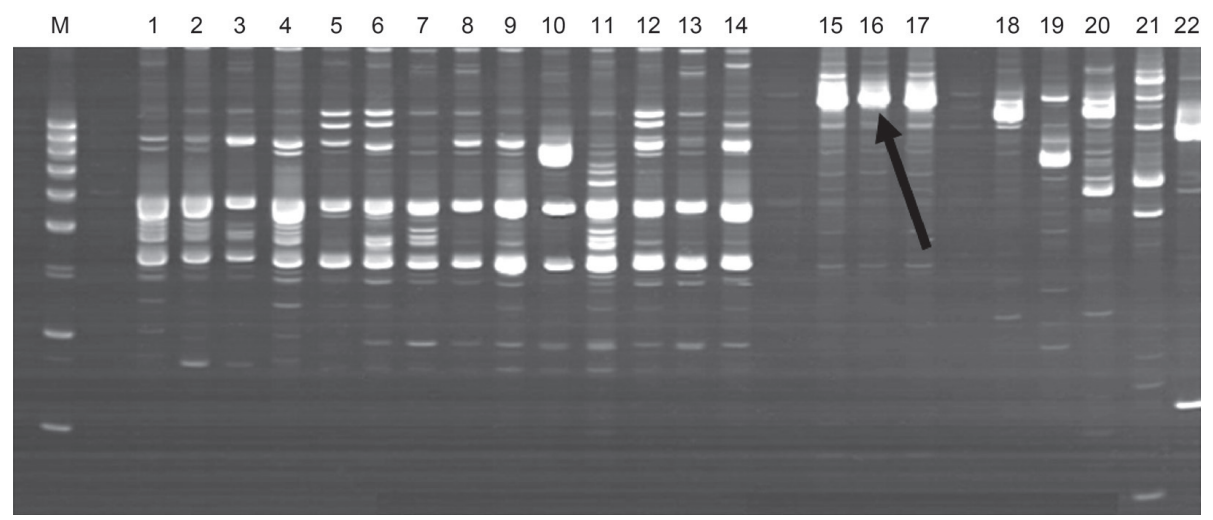

Fig. 1. RAPD patterns obtained with DNA extracted from the following strains: lanes 1-14 C. albicans, lanes 15-17 C. glabrata, lanes 18 and 21 C. parapsilosis, lane 19 C. krusei, lane 20 C. tropicalis, lane 22 C. kefyr. The black arrow indicates the C. glabrata specific PCR product. Lane M: 1000-100 bp DNA marker.

The versatile product represented in lanes number: 15, 16, and 17 of Fig. 1 was excised from the agarose gel and cloned into the pJET1.2 vector. The inserted DNA fragment of resulting recombinant plasmid pJETG1 was sequenced. The sequencing results were compared against the NCBI database. The sequence was identified as Candida glabrata CBS138 hypothetical protein. The sequence number CAGL0M05005g was downloaded from the www.candidagenome.org website and a pair of primers, Cgla272FOR (5’ GAGTGGTATGACGAGCAATGGT 3') and Cgla)272REV (5' TTGTATTGAAGATTCCCTCTCATATATC 3'), was designed.

The theoretical specificity of the primers thus designed, Cgla272FOR and Cgla272REV, was confirmed by blasting their sequences against the NCBI database. The PCR reaction with these primers was performed in an annealing temperature gradient from $50^{\circ} \mathrm{C}$ to $63^{\circ} \mathrm{C}$ and an annealing temperature of $63^{\circ} \mathrm{C}$ was chosen. The versatility of the primers was confirmed, as the specific $272 \mathrm{bp}$ PCR products were detected for all 31 reactions performed with C. glabrata DNA. Their specificity also was confirmed, since no PCR product was detected for the reaction performed with the DNA extracted from 85 different non-C. glabrata isolates. The determination of the sensitivity of this PCR reaction was evaluated by running reactions with a row of $10 \mathrm{x}$ dilution C. glabrata DNA; the DNA concentration in the samples ranged from $212 \mathrm{ng} / \mu \mathrm{l}$ to $0,000212 \mathrm{ng} / \mu \mathrm{l}$. The reaction had the capability of detecting approximately 21 pg of DNA.

The same primers were examined for their potential application in real-time PCR with fluorophore SYBRGreen. Positive results were obtained for the reactions run with C. glabrata $(\mathrm{Cp}<30)$ and negative results were obtained for non-C. glabrata strains (Cp $>40)$. The analysis of the melting profile of C. glabrata PCR products was established as $\sim 86^{\circ} \mathrm{C}$. In addition, the reaction was performed on human DNA and no product was detected. The determination of the real-time PCR reaction sensitivity was evaluated. The reaction was able to detect 2.12 ng of DNA.

To check the limit of detection of the reactions with these primers, PCR and real-time PCR with DNA extracted from C. glabrata-spiked blood samples were performed. The results of the reactions were compared with the number of C. glabrata colonies corresponding to particular dilutions. The limit of detection for both PCR and real-time PCR detection was established as $\sim 1 \mathrm{CFU}$, which permits the presumption of their high potential for application in C. glabrata molecular diagnostics.

\section{Acknowledgments}

The study presented in this article was financed by the Polish Ministry of Science and Higher Education under grant number NN401 221934.

\section{Literature}

Burgener-Kairuz P., J.P. Zuber, P. Jaunin, T.G. Buchman, J. Billie and M. Rossier. 1994. Rapid setection and identification of Candida albicans and Candida glabrata in clinical speciments by species - specific nested PCR amplification of a cytochrome P-450 Lanosterol-Demethylase (L1A1) gene fragment. J. Clin. Microbiol. 32: 1902-1907.

Chen Y., J.D. Eisner, M.M. Kattar, S.L. Rassoulian-Barrett, K. Lafe, U. Bui, A.P. Limaye and B.T. Cookson. 2001. Polimorphic internal transcribed spacer region 1 DNA sequences identify medically important yeasts. J. Clin. Microbiol. 39: 4042-4051.

Ciardo D.E., G. Schar, E.C. Bottger, M. Altwegg and P.P. Bosshard. 2006. Internal transcribed spacer sequencing versus biochemical profiling for identification of medically important yeasts. J. Clin. Microbiol. 44: 77-84.

Fidel P.L., J.A. Vazquez and J.D. Sobel. 1999. Candida glabrata: review of epidemiology, pathogenesis, and clinical disease with comparison to C. albicans. Clin. Microbiol. Rev. 12: 80-96. 
Fujita S., Y. Seneda, S. Nakaguchi and T. Hashimoto. 2001. Multiplex PCR using internal transcribed spacer 1 and 2 regions for rapid detection and identification of yeast strains. J. Clin. Microbiol. 39: 3617-3622

Jordan J.A. 1994. Identification of four medically important Candida species by using a single primer pair. J. Clin. Microbiol. 32: 2962-2967.

Luo G. and T.G. Mitchell. 2002. Rapid identification of pathogenic fungi directly from cultures by using multiplex PCR. J. Clin. Microbiol. 40: 2860-2865.
Lyon G.M., S. Karatela, S. Sunay and Y. Adiri. 2010. Antifungal Susceptibility Testing of Candida Isolates from the Candida Surveillance Study. J. Clin. Microbiol. 48: 1270-1275.

Mecler I. and U. Nawrot. 2008. Molecular methods of Candida identification. Mikol. Lek. 15: 99-103.

Pfaller M.A., D.J. Diekema, S.A. Messer, L. Boyken and R.J. Hollis. 2003. Activities of fluconazole and voriconazole against 1,586 recent clinical isolates of Candida species determined by broth microdilution, disk diffusion, and Etest methods: report from the ARTEMIS Global Antifungal Susceptibility Program 2001. J. Clin. Microbiol. 41: $1440-1446$ 